\title{
Possibilities of using functional biologically active organosilicon compounds in veterinary practice
}

\author{
A. S. Barkova ${ }^{1 凶}$, E. I. Shurmanova ${ }^{1}$, T. G. Khonina ${ }^{1,2}$, I. M. Millstein ${ }^{1}$ \\ ${ }^{1}$ Ural State Agrarian University, Ekaterinburg, Russia \\ ${ }^{2}$ Postovsky Institute of Organic Synthesis of Ural Branch of the Russian Academy of Science, Ekaterinburg, \\ Russia \\ E-mail: barkova.as@mail.ru
}

\begin{abstract}
Purpose. Evaluation of the possibility of using silicon, silicon-zinc, silicon-zinc organoboron compounds and compositions based on them for the treatment and prevention of inflammatory and non-inflammatory diseases in agricultural and small domestic animals. Method. There was carried out a clinical trial of various medicinal compositions with a base in the form of organic compounds of silicon, zinc, boron, both containing antimicrobial components and environmentally friendly agents. For this purpose, groups of animals were formed on the principle of analogs. The multiplicity and administration of drugs depended on the studied pathology. Results. The obtained results showed a high efficiency of the studied compositions, in particular, in the treatment of postpartum diseases of the uterus of an inflammatory nature, the effectiveness of the application was $95.5 \%$, with conservative treatment of the retention of the placenta $-100 \%$. Also, these funds are highly effective for the treatment of hyperkeratosis of the udder nipples, without changing the technology of milking. On average, the effectiveness of the compositions reached $86.1 \%$ when the funds were used for 7 days. The study of an antimicrobial composition based on organosilicon glycerohydrogel in the treatment of purulent-necrotic lesions in the distal part of the extremities in cows can reduce the frequency of procedures and the duration of treatment by 6 days compared to animals in the control group. Scientific novelty. New functional biologically active pharmacological agents based on silicon-, silicon-zinc-, silicon-zinc boron glycerohydrogels have been developed and clinically tested for the treatment of cows with postpartum uterine diseases, in particular, postpartum endometritis and retention of the placenta, hyperkeratosis of the udder nipples, purulent-necrotic diseases of the distal also necrotic skin lesions of small domestic animals.
\end{abstract}

Keywords: organosilicon compounds, cows, postpartum endometritis, hyperkeratosis, distal extremities, necrotic lesions.

For citation: Barkova A. S., Shurmanova E. I., Khonina T. G., Milstein I. M. Possibilities of using functional biologically active organosilicon compounds in veterinary practice // Agrarian Bulletin of the Urals. 2020. No. 11 (202). Pp. 53-58. DOI: ...

Paper submitted: 12.09.2020.

\section{Introduction}

Diseases of the reproductive system organs, mammary gland, and extremities cause significant economic damage to the dairy farming industry and significantly reduce the profitability of the dairy farming industry [1, p. 59], [4, p. 35], [8, p. 38]. An analysis carried out by a number of researchers showed a high degree of spread of both diseases of the breast and the reproductive system [2, p. 201], [5, p. 64], [12, p. 37], $[13$, p. 119]. At the same time, the use of antimicrobial drugs for the treatment and prevention of these diseases is associated with the forced rejection of milk for the period of treatment of animals. An analysis carried out by a number of researchers showed a high degree of spread of both diseases of the breast and the reproductive system [2, p. 201], [5, p. 64], [12, p. 37], $[13$, p. 119]. At the same time, the use of antimicrobial drugs for the treatment and prevention of these diseases is associated with the forced rejection of milk for the period of treatment of animals. In this regard, the development of modern and environmentally friendly therapeutic and prophylactic agents is an urgent task for specialists in various fields of activity [6, p. 85; 7 , p. 25,16 , p. 1877]. In particular, one of the modern areas of chemical and pharmacological science is the development of agents based on organosilicon compounds.

Until 2013 Department of Surgery, Obstetrics and Microbiology under the leadership of Professor Anna F. Kolchina with the Institute of Organic Synthesis named after I. Ya. Postovsky, in particular, Doctor of Chemistry Tatyana G. Khonina has been studying the effectiveness and possible applications of biologically active organosilicon compounds in veterinary practice for more than 10 years [3, p. 18], [10, p. 62], [15, p. 1881].

Due to the fact that the basis can have a significant effect on the effectiveness of a drug, the development of its optimal composition remains an urgent issue. In particular, a modern and promising direction of research is the synthesis of organic compounds based on essential trace elements, in particular silicon, zinc and boron. Institute of Organic Synthesis named after I. Ya. Postovsky of the Ural Branch of the Russian Academy of Sciences for a number of years has been engaged in the synthesis of organosilicon compounds, in particular, the employees of the institute have patented silicon glycerolates with transcutaneous conductivity of drugs, as well as hy- 
drogels based on them: silicon-containing glycerohydrogel $\mathrm{Si}\left(\mathrm{C}_{3} \mathrm{H}_{7} \mathrm{O}_{3}\right)_{4} \cdot 6 \mathrm{C}_{3} \mathrm{H}_{8} \mathrm{O}_{3} \cdot 24 \mathrm{H}_{2} \mathrm{O}$ (Patent RF 2255939, 2005), substance: (2,3-dioxypropyl)-ortho-silicate glycerohydrogel: preparation "Silativit", water-soluble dimethylglycerolates of silicon $\left(\mathrm{CH}_{3}\right)_{2} \mathrm{Si}\left(\mathrm{C}_{3} \mathrm{H}_{7} \mathrm{O}_{3}\right)_{2} \cdot \mathrm{xC}_{3} \mathrm{H}_{8} \mathrm{O}_{3}, \mathrm{x}=0.25-1.0$ (Patent RF 2382046, 2010), silicon-zinc-containing glycerohydrogel $2 \mathrm{Si}\left(\mathrm{C}_{3} \mathrm{H}_{7} \mathrm{O}_{3}\right)_{4} \cdot \mathrm{ZnC}_{3} \mathrm{H}_{6} \mathrm{O}_{3} \cdot 14 \mathrm{C}_{3} \mathrm{H}_{8} \mathrm{O}_{3} \cdot 80 \mathrm{H}_{2} \mathrm{O}$ (RF Patent 2520969, 2014), silicon-containing glycerohydrogel $\mathrm{Si}\left(\mathrm{C}_{3} \mathrm{H}_{7} \mathrm{O}_{3}\right)_{4} \cdot \mathrm{HB}\left(\mathrm{C}_{3} \mathrm{H}_{6} \mathrm{O} 3\right) 2 \cdot 8 \mathrm{C} 3 \mathrm{H} 8 \mathrm{O} 3 \cdot 28 \mathrm{H} 2 \mathrm{O}$ (Patent RF 2601312, 2016), silicon-zinc-boron-containing glycerohydrogel $3 \mathrm{Si}\left(\mathrm{C}_{3} \mathrm{H}_{7} \mathrm{O}_{3}\right)_{4} \cdot \mathrm{ZnC}_{3} \mathrm{H}_{6} \mathrm{O}_{3} \cdot 2 \mathrm{HB}\left(\mathrm{C}_{3} \mathrm{H}_{6} \mathrm{O}_{3}\right)_{2} \cdot 8 \mathrm{C} 3 \mathrm{H} 8 \mathrm{O} 3$. 28H2O (RF Pat. 2601312, 2016), silicon-zinc boron-containing glycerohydrogel $3 \mathrm{Si}\left(\mathrm{C}_{3} \mathrm{H}_{7} \mathrm{O}_{3}\right)_{4} \cdot \mathrm{ZnC}_{3} \mathrm{H}_{6} \mathrm{O}_{3} \cdot 2 \mathrm{HB}$ $\left(\mathrm{C}_{3} \mathrm{H}_{6} \mathrm{O}_{3}\right)_{2} \cdot 15 \mathrm{C}_{3} \mathrm{H}_{8} \mathrm{O}_{3} \cdot 70 \mathrm{H}_{2} \mathrm{O}$ (Pat. $\left.2623153 \mathrm{RF}, 2017\right)$

These compounds are economical and easy to obtain, nontoxic, do not accumulate, do not cause local and systemic allergic reactions, have a beneficial effect on the processes of tissue repair and regeneration, have a pronounced transcutaneous conductivity, anti-edema effect, and increase tissue oxygenation. An important property of these bases is their structural compatibility with the lipid component of cell membranes, as well as compatibility with most drugs [9, p. 1627], [11, p. 562], [14, p. 225].

In this regard, a number of pharmacological compositions with different bases were developed and their clinical testing was carried out in agricultural enterprises of the Sverdlovsk region for the prevention and treatment of inflammatory diseases of the organs of the reproductive system of cows, as well as the mammary gland and purulent-necrotic lesions in the distal part of the extremities, as well as of necrotic skin lesions in small pets at the animal rehabilitation center of the Ural State Agrarian University.

\section{Methods}

The study of the effectiveness of pharmacological compositions for the treatment and prevention of postpartum endometritis, hyperkeratosis of the udder nipples was carried out on the basis of a number of agricultural enterprises in the Sverdlovsk region with the formation of groups of animals according to the principle of analogues.

For the treatment and prevention of diseases of the udder nipples, the investigational agents were applied to the udder nipples immediately after milking, 2 times a day for an aver-
Аграрный вестник Урала № 11 (202), 2020 г.

age of 7 days. When evaluating the results, was assessed the condition of the skin of the nipples of the mammary gland, taking into account the severity and outer diameter of circular calluses in the area of the opening of the nipple canal, ultrasonic criteria for the presence of pathological tissues in the lumen of the nipple canal, as well as the presence of subclinical mastitis in the quarters of the udder.

In the treatment of purulent-necrotic lesions in the distal extremities and skin, the investigational agents were applied to the affected areas 1 time in 3 days until the completion of the primary repair processes. In the treatment of necrotic skin lesions in small pets, the investigational agents were applied in a thin layer directly to the area of damage from 6 to 8 days, once every 24 hours.

\section{Results}

The staff of the department have been engaged in the development and testing of drugs for the treatment of acute postpartum endometritis for a number of years. Due to the high incidence of inflammatory diseases of the uterus in the postpartum period, a liquid antimicrobial composition based on a water-soluble organosilicon derivative of glycerin was included in the complex treatment regimen for postpartum endometritis, including: pefloxacin $-1.00 \mathrm{wt} \%$; metronidazole -1.00 wt $\%$; chlorhexidine bigluconate $-0.05 \mathrm{wt} \%$; silicon dimethylglycerolates $\mathrm{Me}_{2} \mathrm{Si}\left(\mathrm{C}_{3} \mathrm{H}_{7} \mathrm{O}_{3}\right)_{2} \cdot \mathrm{C}_{3} \mathrm{H}_{8} \mathrm{O}_{3}$ - the rest.

The composition was administered to animals intrauterinely with an interval of 48 hours, in a volume of $100 \mathrm{ml}$, previously diluted in a ratio of $1: 2$ with sterile water, the frequency of administration was from 3 to 5 times. To cows of the control group, intrauterine administration of the drug genobiotic, foaming tablets, was used as antimicrobial therapy, according to the instructions. The assessment of the condition of the genitals was carried out on 7th, 14th, 21st days after calving using a gynecological examination.

The obtained results showed that the treatment period for animals in the experimental group was about 12 days with an efficiency of $95.5 \%$, and in the control group - about 18 days, with an efficiency of $86.4 \%$. (fig. 1) At the same time, the animals of the experimental group showed a reduction in the recovery time of the sexual cycle and the service period in the cows of the experimental group, and they also showed an increase in fertilization from the first insemination.

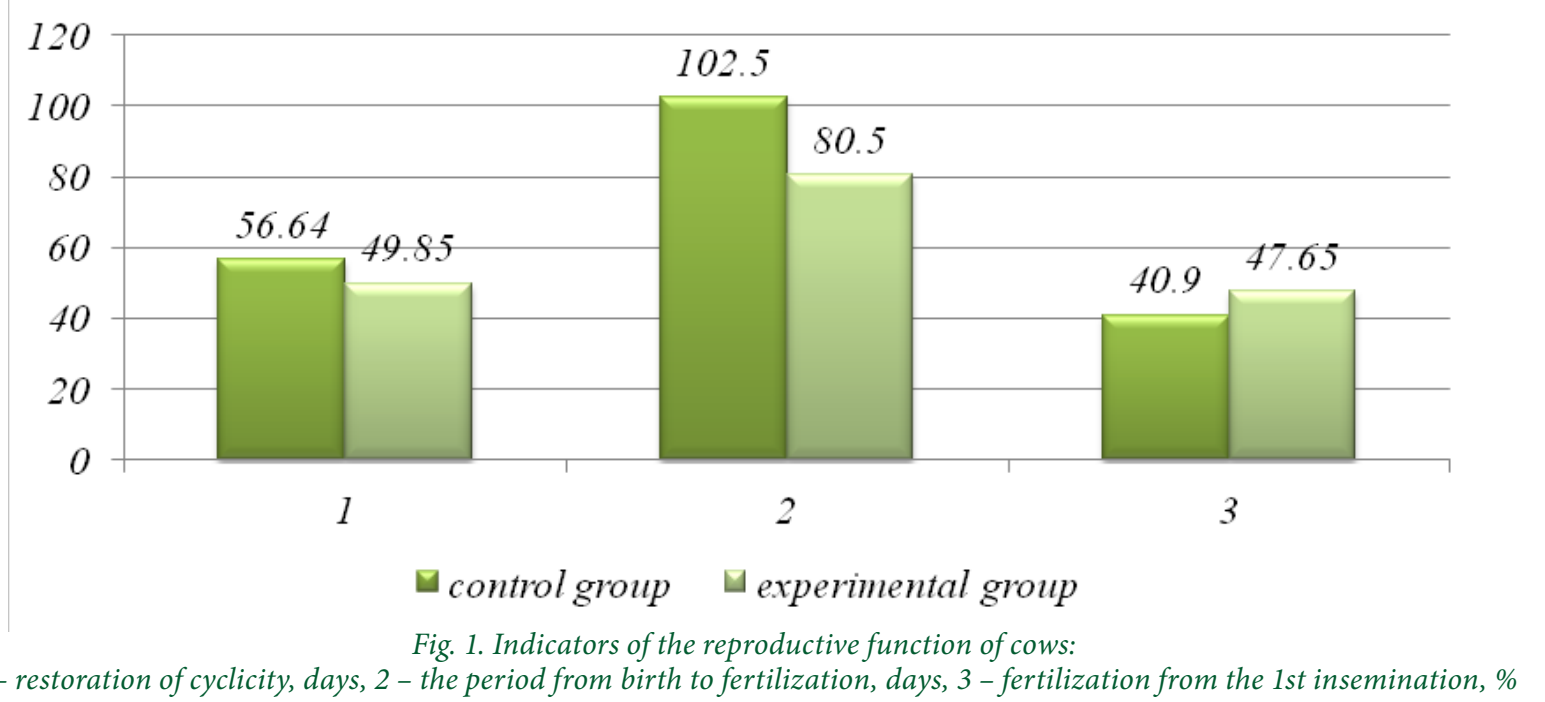




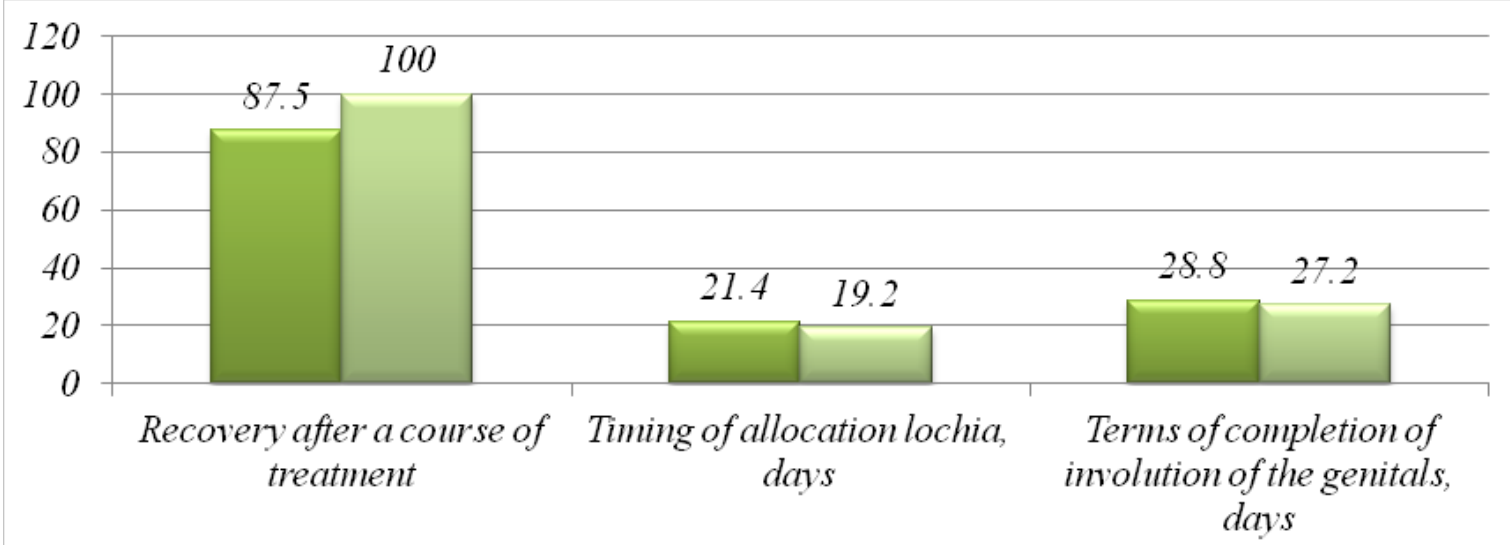

\section{\control group $\square$ experimental group}

Fig. 2. The effectiveness of treatment of cows using a composition containing $\mathrm{CO}_{2}$-extract of calendula and silicon glycerolates

However, this composition contains antibiotics, which may somewhat limit its use. In this regard, a composition was proposed based on silicon glycerolates, including $0.5 \%-$ supercritical $\mathrm{CO}_{2}$ extract of calendula: $\mathrm{CO}_{2}$ extract of calendula $-0.50 \mathrm{wt} \%$; silicon dimethylglycerolates $\mathrm{Me}_{2} \mathrm{Si}\left(\mathrm{C}_{3} \mathrm{H}_{7} \mathrm{O}_{3}\right)_{2}$, $\mathrm{C}_{3} \mathrm{H}_{8} \mathrm{O}_{3}$ - the rest. The supercritical $\mathrm{CO}_{2}$ extract of calendula added to the composition of the product has an anti-inflammatory effect and improves the processes of epithelial regeneration. Evaluation of the effectiveness of the composition was carried out on a group of animals with the retention of the placenta and using a conservative method of treating this pathology.

After the end of treatment, the cows of the experimental group showed complete recovery in $100 \%$ of cases, while two animals from the control group needed an additional treatment course, that is, its effectiveness was $87.5 \%$ (fig. 2). In addition, the cows of the experimental group, relative to the control, recorded a positive tendency to accelerate the recovery of the uterus in the postpartum period, in particular, the period from birth to fertilization in the experimental group was $92.69 \pm$ 2.80 days, which is 11.93 days less than control.

Thus, on the basis of the carried out studies, it can be concluded that the use of liquid medicinal compositions based on a water-soluble organosilicon glycerin derivative as part of complex treatment regimens for cows with postpartum endometritis and retention of the placenta is effective and requires further research.

The second line of research on the effectiveness of the developed compositions is the treatment and prevention of udder diseases in cows during lactation. In this regard, a number of compositions have been developed in the form of various dosage forms, in particular gels and liquid forms.

The composition based on silicon glycerolates, containing $0.5 \%$ supercritical $\mathrm{CO}_{2}$ extract of calendula, was tested for the treatment of subclinical mastitis in lactating cows. The agent was administered intercisternally, $10 \mathrm{ml}$, once a day for 4 days. As a result, $50 \%$ of the cows showed recovery, confirmed by a negative reaction with a rapid mastitis test and a sedimentation test.

One of the problems of the dairy farming industry is udder teat hyperkeratosis, which is widespread in agricultural enterprises with a high level of dairy productivity. At the same time, hyperkeratosis is a predisposing cause of mastitis in cows, as well as premature culling of animals, since the tissues of the nipple canal are destroyed, which leads to a violation of its barrier function.

In this regard, for a number of years, we have conducted researches on various medicinal compositions for the treatment and prevention of diseases of the udder nipples.

Compositions based on "Silativit", organosilicon glycerohydrogel, containing antimicrobial drugs (pefloxacin, metronidazole, chlorhexidine), $0.5 \%$ supercritical $\mathrm{CO}_{2}$ extract of calendula, $1 \%$ "Vetoron", $4.2 \%$ zinc monoglycerolates, as well as agents such as organosiliconzinc and organosiliconzincboron glycerohydrogels.

One of the advantages of the developed functional biologically active compositions based on glycerohydrogels of silicon, zinc and boron is the possibility of their use without changing the mode of machine milking of cows, while ensuring recovery of up to $86.1 \%$ of affected udder quarters. These pharmacological agents have a pronounced prolonged action, which allows them to be harmoniously included in the milking process. The average duration of using the products is about 7 days, when applied 2 times a day, immediately after milking. The prolonged action lasts for 3-4 weeks after the end of their application without changing the milking regime of cows.

In particular, when using organosilicon-zinc glycerohydrogel before the start of treatment, nipples with a physiological reaction were not observed, 14 days after the end of application of the product, their number was $58.4 \%$. At the same time, the number of quarters with a complicated form of hyperkeratosis decreased 5.1 times (fig. 3).

Ultrasound studies of the condition of the nipple canal with the determination of hyperechoic deposits of keratin in its lumen showed a significant decrease in the volume of the affected tissues in the lumen of the nipple canal. The above sonograms show a decrease in the echogenicity of the nipple canal tissues, which before treatment are represented by hyperechoic overlays on the mucous membrane and a funnel-shaped expansion in the projection of the nipple canal opening. 2 weeks after the end of the application of the agent, the damaged tissues are completely restored, the stratum corneum of the epithelium is rejected, which is confirmed by the absence of hyperechoic formations in the area of the external opening of the nipple canal during ultrasound examination. 


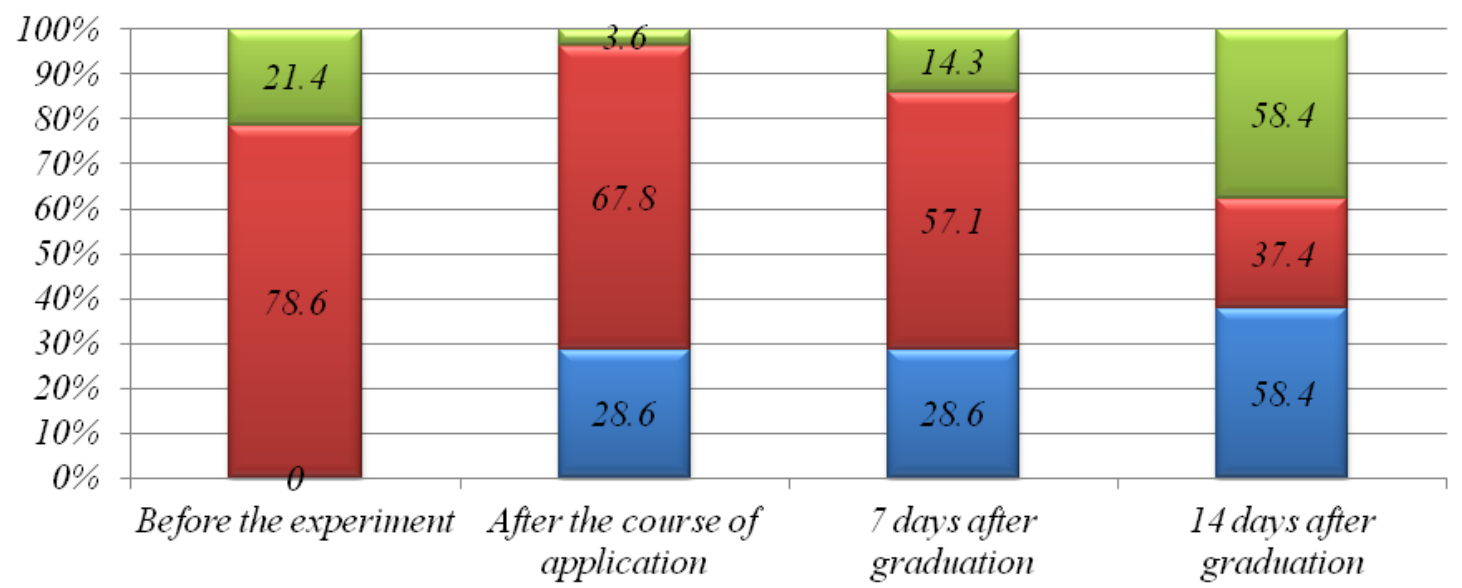

$\square$ Physiological reaction $\square$ Hyperkeratosis $\square$ Complicated hyperkeratosis

Fig. 3. Condition of udder teats when using Se-Zn-organic glycerohydrogel

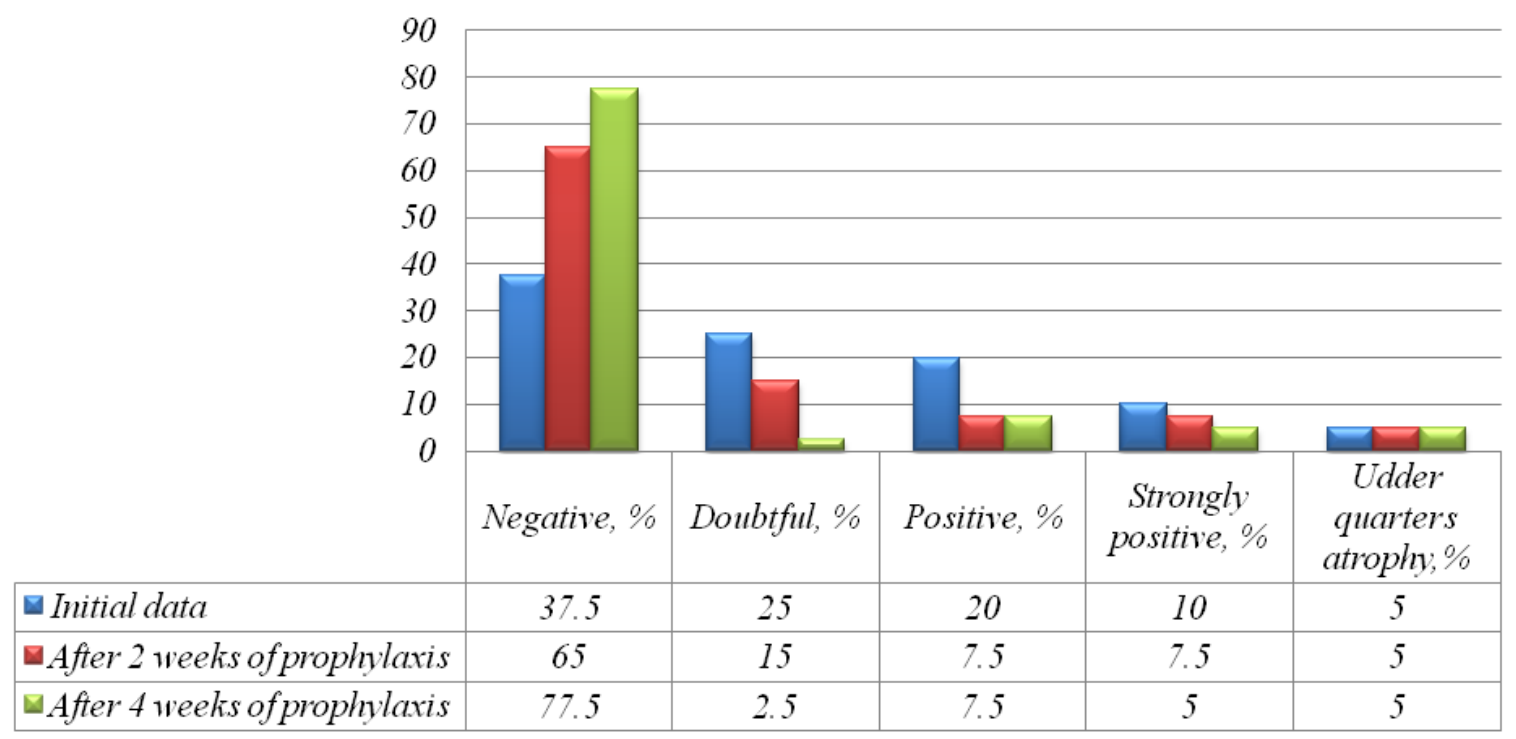

Fig. 4. The spread of latent mastitis when using the developed prophylactic agent

In connection with the revealed clinical efficacy of the investigated agents, a liquid pharmaceutical composition based on silicon dimethylglycerolates was proposed with the following composition: silicon dimethylglycerolate $-5 \%$; silicon glycerolate $-1 \%$; boron glycerolate $-1 \%$; zinc glycerolate $1 \%$; glycerin $-16.65 \%$; xanthan gum $0.35 \%$; water - the rest is up to $100 \%$.

This agent was applied daily after each milking to the teats of the udders of cows for 4 weeks using an udder cup. The results showed that the level of complicated hyperkeratosis decreased 2 times, uncomplicated hyperkeratosis -2.5 times relative to the initial data, while the number of udder quarters with a negative reaction with a rapid mastitis test increased 2 times, which showed its high preventive effectiveness (fig. 4).

Also, the approbation of the developed means was carried out in the treatment of purulent-necrotic lesions of the hooves in cows. Antimicrobial composition based on "Silativit" of the following composition: pefloxacin $-1.00 \mathrm{wt} \%$; metronidazole - $1.00 \mathrm{wt} \%$; chlorhexidine bigluconate $-0.05 \mathrm{wt} \%$; "Silativit" - the rest, was applied directly to the affected area, injected into the cavities of the defects once every 3 days, followed by fixation with a cotton-gauze bandage. The use 56 of drugs was stopped after the completion of the process of primary tissue organization (primary repair), normalization of the natural position of the limbs, and the absence of lameness. The course of treatment ranged from 9 to 15 procedures, on average 12 (39 days), in the control group - on average 15 procedures (45 days).

We also studied the effectiveness of a liquid composition based on silicon dimethylglycerolates containing silicon and boron glycerolates for the treatment of purulent and purulentnecrotic processes in small pets. Our studies on the basis of the Animal Rehabilitation Center of the Ural State Agrarian University have shown that the use of this agent promotes accelerated tissue regeneration and has a pronounced antiinflammatory effect. The agent was applied once a day until a positive effect was obtained, on average about 7 days. When treating a wound in the neck from an ingrown collar, after 6 days of using the agent, complete closure of the wound defect is noted (fig. 5). When the agent was applied in the area of tissue necrosis in the suture area after surgery to remove mammary gland tumors in a dog, after 8 days of using the agent there was noted an active process of wound regeneration and epithelialization (fig. 6). 


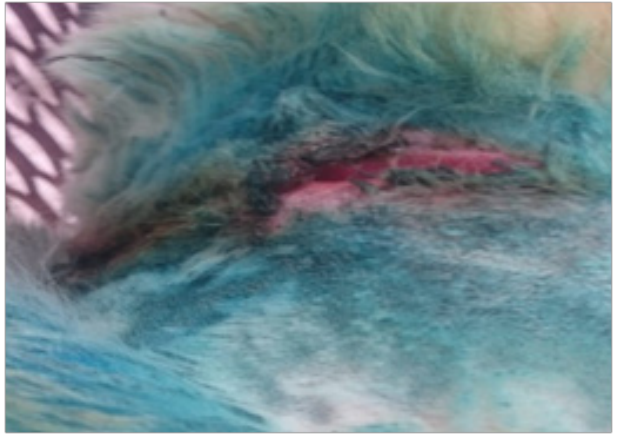

A

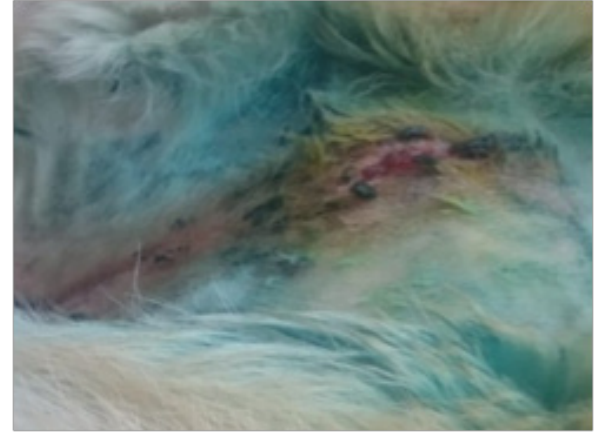

$B$

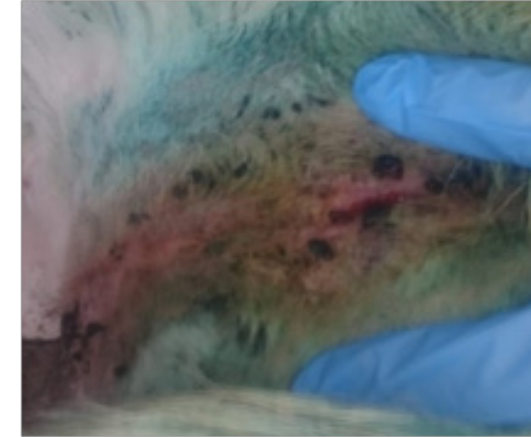

C

Fig. 5. Wound in the neck from an ingrown collar: A - before using the product (wound $12 \times 2 \mathrm{~cm}$ );

$B-4$ days after starting to use the product (wound $4 \times 1 \mathrm{~cm}$ ); C -6 days after the start of application of the product (wound $2 \times 0.5 \mathrm{~cm})$

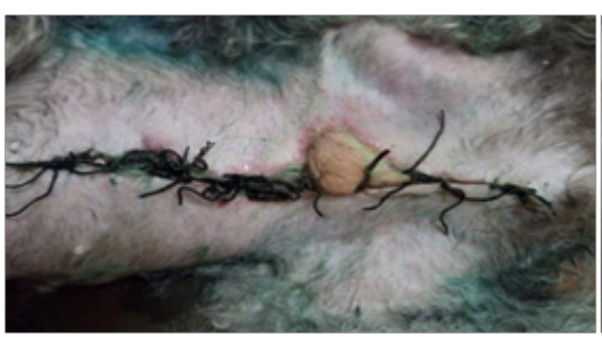

$A$

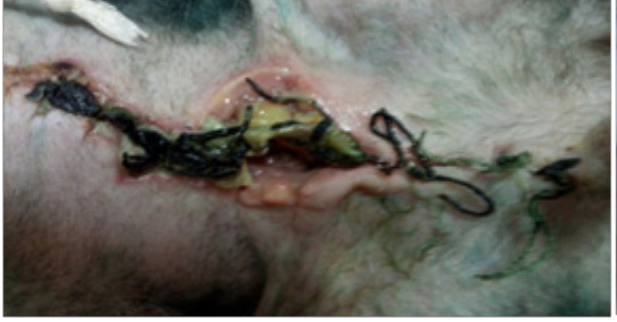

$B$

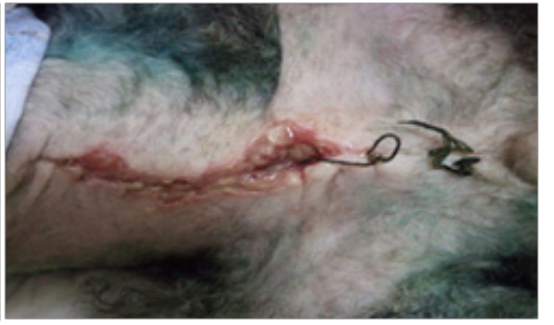

C

Fig. 6. Necrosis in the suture area after surgery to remove breast tumors in a dog:

$A$ - before using the agent, $B$ - after 4 days of using the agent, $C$ - after 8 days of using the agent

\section{Discussion and Conclusion}

Thus, we can conclude that the development of new agents and compositions based on organosilicon glycerohydrogels is a promising direction, which is associated with a wide range of possibilities for their use in veterinary practice. These funds have therapeutic and prophylactic activity when used in their pure form, as well as when used as active bases of pharmacological compositions. The problems of using various compo- sitions in pathological processes in small domestic animals, as well as in the treatment and prevention of inflammatory diseases of the distal limb in animals, remain poorly studied. Based on the results of the work carried out at the Department of Surgery, Obstetrics and Microbiology, were defended 6 dissertations, including 2 doctoral dissertations, were received 6 RF patents for inventions.

\section{References}

1. Bagmanov M. A., Yusupov S. R., Fayzrakhmanova R. N. Rezul'taty akushersko-ginekologicheskoy dispanserizatsii korov [Results of obstetric and gynecological clinical examination of cows] // Uchenye zapiski Kazanskoy gosudarstvennoy akademii veterinarnoy meditsiny im. N. E. Baumana. 2011. T. 207. Pp. 57-60. (In Russian.)

2. Batrakov A. Ya., Plemyashov K. V., Videnin V. N., Yashin A. V. Meropriyatiya, napravlennye na profilaktiku zabolevaniya korov mastitami [Measures aimed at preventing mastitis in cows] // Mezhdunarodnyy vestnik veterinarii. 2020. No. 2. Pp. 199203. DOI: 10.17238/issn2072-2419.2020.199. (In Russian.)

3. Elesin A. V., Kurysheva M. V., Zabrodin E. A., Pelevina E. A., Khonina T. G., Tosova I. N. Effektivnost' ispol'zovaniya kompozitsii na osnove "Silativita" pri gnoyno-nekroticheskikh porazheniyakh kopytets vysokoproduktivnykh korov [The effectiveness of using the composition based on "Silativit" in purulent-necrotic lesions of the hooves of highly productive cows] // Agrarian Bulletin of the Urals. 2011. No. 12-2 (92). Pp. 17-18. (In Russian.)

4. Zubkova L. I., Zvereva E. A., Andrianov L. V. Vliyanie zabolevaniy vymeni na molochnuyu produktivnost' korov [Influence of udder diseases on milk productivity of cows] // Dairy and beef cattle farming. 2015. No. 4. Pp. 35-37. DOI: 10.12737/12513. (In Russian.)

5. Isakova M. N., Ryaposova M. V., Bezborodova N. A., Britsina O. A. Mikrobiologicheskiy fon pri vospalenii molochnoy zhelezy u vysokoproduktivnykh korov [Microbiological background in inflammation of the mammary gland in highly productive cows] // Problems on Veterinary Sanitation, Hygiene and Ecology. 2017. No. 2 (22). Pp. 63-67. (In Russian.)

6. Kovalenko A. M., Kokolov K. S., Kuz'min V. A. Razrabotka i aprobatsiya sredstva dlya lecheniya krupnogo rogatogo skota s zabolevaniyami distal'nogo otdela konechnostey [Development and testing of a remedy for the treatment of cattle with diseases of the distal extremities] // Issues of Legal Regulation in Veterinary Medicine. 2017. No. 2 (11). Pp. 83-86. (In Russian.)

7. Novikova E. N., Koba I. S., Shevchenko A. N., Reshetka M. B Metod profilaktiki akushersko-ginekologicheskoy patologii $\mathrm{u}$ korov [Method of prevention of obstetric and gynecological pathology in cows] // Veterinariya i kormlenie. 2018 . No. 6. Pp. 25-26. DOI: 10.30917/ATT-VK-1814-9588-2018-6-9. (In Russian.) 
8. Surkov R. A. Sravnitel'nyy opyt profilaktiki zabolevaniy distal'nogo otdela konechnostey krupnogo rogatogo skota [Comparative experience in the prevention of diseases of the distal limbs of cattle] // Nauchnyy zhurnal molodykh uchenykh. 2018. No. 2 (11). Pp. 36-40. (In Russian.)

9. Khonina T. G., Chupakhin O. N., Kungurov N. V., Zil'berberg N. V., Evstigneeva N. P., Kokhan M. M., Polishchuk A. I., Permikina E. Yu., Larionov L. P. Sintez i farmakologicheskaya aktivnost' kremniyborsoderzhashchego glitserogidrogelya [Synthesis and pharmacological activity of silicon boron-containing glycerohydrogel] // Russian Chemical Bulletin. 2019. No. 8. Pp. 1621-1628. (In Russian.)

10. Tomskikh A. S., Barashkin M. I., Barkova A.S., Shurmanova E. I. Otsenka effektivnosti lecheniya pri giperkeratoze soskov vymeni [Evaluation of the effectiveness of treatment for hyperkeratosis of the udder nipples] // Agrarian Bulletin of the Urals. 2016. No. 8 (150). Pp. 58-63. (In Russian.)

11. Chupakhin O. N., Khonina T. G., Kungurov N. V., Zil'berberg N. V., Evstigneeva N. P., Kokhan M. M., Polishchuk A. I., Shadrina E. V., Larchenko E. Yu., Larionov L. P., Karabanalov M. S. Kremniyborsoderzhashchiy glitserogidrogel', obladayushchiy ranozazhivlyayushchey, regeneriruyushchey i antimikrobnoy aktivnost'yu [Siliconboron-containing glycerohydrogel with wound-healing, regenerating and antimicrobial activity] // Russian Chemical Bulletin. 2017. No. 3. Pp. 558-563. DOI: 10.1007/s11172-017-1771-2. (In Russian.)

12. Yakhaev I. M., Fedotov S. V., Belozertseva N. S. Ginekologo-mammologicheskaya dispanserizatsiy alaktiruyushchikh korov [Gynecological and mammological clinical examination of lactating cows] // Veterinary. 2020. No. 6. Pp. 33-38. DOI: 10.30896/0042-4846.2020.23.6.33-38. (In Russian.)

13. Yakhaev I. M., Fedotov S. V., Belozertseva N. S. Gynecological and mammological clinical examination of lactating cows // Veterinarnaya meditsina. 2020. No. 6. Pp. 33-38. DOI: 10.30896/0042-4846.2020.23.6.33-38.

14. Batrakov A., Videnin V., Yashin A., Nechaev A., Anipchenko P., Filatova A., Alekhin Yu. N. Treatment of cows with subclinical mastitis // Reproduction in Domestic Animals. 2019. T. 54. No. S3. Pp. 119.

15. Khonina T. G., Shadrina E. V., Larchenko E. Y., Shipovskaya A. B., Malinkina O. N., Zudina I. V. Formation features, properties and biomedical applications of silicon-chitosanc ontaining glycerohydrogels // Advances in Chemistry Research. 2017. Pp. 193-226. DOI: 10.1007/s11172-015-1053-9.

16. Loretts O. G., Barkova A. S., Elesin A. V., Khonina T. G., Shurmanova E. I., Barashkin M. I., Millstein I. M. Dissemination, etiology, pathogenesis and treatment of cattle teatdiseases in agricultural organizations of the Sverdlovsk region of Russian Federation // Research Journal of Pharmaceutical, Biological and Chemical Sciences. 2018. No. 9 (5). Pp. $1867-1882$.

17. Yusupov S. R., Smolentsev S. Yu., Churina Z. G., Yusupova G. R., Hasanov A. R., Galimzyanov I. G., Krupin E. O., Konopeltsev I. G. Comparative efficiency of sepranol and cefamethrin use in postpartum acute endometritis in cows // International Journal of Research in Pharmaceutical Sciences. 2020. T. 11. No. 2. Pp. 1874-1878. DOI: 10.26452/ijrps.v11i2.2096.

\section{Authors' information:}

Anna S. Barkova ${ }^{1}$, doctor of veterinary sciences, associate professor, professor of the department of surgery, obstetrics and microbiology, ORCID 0000-0002-2602-6810, AuthorID 610629; +7 908 903-28-36, barkova.as@mail.ru

Evgeniya I. Shurmanova ${ }^{1}$, candidate of veterinary sciences, associate professor of the department of surgery, obstetrics and microbiology, ORCID 0000-0003-2466-8016, AuthorID 484858

Tatyana G. Khonina ${ }^{1,2}$, doctor of chemical sciences, professor of the department of chemistry, soil science and agroecology ${ }^{1}$; leading researcher ${ }^{2}$, ORCID 0000-0002-8746-7046 AuthorID 55591

Igor M. Millstein ${ }^{1}$, candidate of veterinary sciences, associate professor, associate professor of the department of surgery, obstetrics and microbiology, ORCID 0000-0001-6293-718X, AuthorID 816877

${ }^{1}$ Ural State Agrarian University, Ekaterinburg, Russia

${ }^{2}$ Postovsky Institute of Organic Synthesis of Ural Branch of the Russian Academy of Science, Ekaterinburg, Russia 